Maurer School of Law: Indiana University Digital Repository@Maurer Law

Indiana Law Journal

Volume 81 | Issue 4

Article 10

Fall 2006

\title{
The War Powers Outside the Courts
}

William Michael Treanor

Fordham University School of Law

Follow this and additional works at: https://www.repository.law.indiana.edu/ilj

Part of the Constitutional Law Commons, Courts Commons, Legislation Commons, and the Military, War, and Peace Commons

\section{Recommended Citation}

Treanor, William Michael (2006) "The War Powers Outside the Courts," Indiana Law Journal: Vol. 81 : Iss. 4 , Article 10.

Available at: https://www.repository.law.indiana.edu/ilj/vol81/iss4/10

This Symposium is brought to you for free and open access by the Law School Journals at Digital Repository @ Maurer Law. It has been accepted for inclusion in Indiana Law Journal by an authorized editor of Digital Repository@Maurer Law. For more information, please contactrvaughan@indiana.edu.

\section{$\Psi$}

JEROME HALL LAW LIBRARY

INDIANA UNIVERSITY

Maurer School of Law
Bloomington 


\title{
The War Powers Outside the Courts ${ }^{\dagger}$
}

\author{
WILLIAM MiChaEL TREANOR*
}

\section{THE PROBLEMS}

Few areas of constitutional law have produced as much heated debate as the war powers area, heat produced in no small part by the passionate belief that this is a subject of incalculable consequence. But, stunningly and ironically, there is little connection between the issues that scholars debate and the constitutional issues involving war that government officials and political leaders confront.

War powers scholarship continues to be haunted by the War in Vietnam, and the dominant question continues to be whether Congress must approve large-scale, sustained military action. But this is not the central issue now (if ever it truly was, since President Johnson could always point to the Gulf of Tonkin Resolution ${ }^{\mathrm{l}}$ ). This is not to say that there is no political actor who still articulates the view that the Executive can unilaterally initiate major conflict and sustain that conflict in the absence of congressional authorization of some form. The first President Bush, for example, made claims to that effect before and after the Gulf War. ${ }^{2}$ But he ultimately went to Congress for authorization. ${ }^{3}$ The debate about whether Congress must authorize large-scale military conflict in the absence of some emergency is one in which champions of the pro-Congress have prevailed as a practical matter. As defenders of executive branch actions justify military action taken or prepare justification for actions under consideration, they either rely on congressional authorization of some type or argue that there is some exception warranting departure from the general principle that Congress must authorize conflict. Thus, to the extent that I can deduce internal deliberations from reading newspapers, as the current administration prepared for war against Iraq, it was not ready to do so simply on the grounds that there is a general executive power to start and wage war without congressional authorization. But Administration lawyers did conclude that war against Hussein could be started in 2002 when the President's constitutional powers were combined with the congressional authorization of the Gulf War in $1991 .^{4}$ Although the Administration eventually

$\dagger$ This Article originally appeared in ThE CONSTTIUTION IN WARTIME (Mark Tushnet ed., 2005). It appears here with the permission of the Duke University Press.

* Dean, Fordham University School of Law.

1. For a good discussion, see JOHN HART ELY, WAR AND RESPONSIBILITY: CONSTTTUTIONAL LESSONS OF VIETNAM AND ITS AFTERMATH 15-23 (1993).

2. See Remarks of President George Bush Before the Texas State Republican Convention, Federal News Service, June 20, 1992, available in LEXIS, News Library, Script File; George Bush, Remarks at Dedication Ceremony of the Social Sciences Complex at Princeton University in Princeton, New Jersey, 27 Weekly Comp. Pres. DoC. 589, 590 (May 10, 1991); George Bush, Statement on Signing the Resolution Authorizing the Use of Military Force Against Iraq, 27 WeEKLy COMP. Pres. DoC. 48 (Jan. 14, 1991).

3. Authorization for Use of Military Force Against Iraq Resolution, Pub. L. No. 102-1, 105 Stat. 3, 3-4 (1991).

4. See Mike Allen \& Juliet Eilperin, Bush Aides Say Iraq War Needs No Hill Vote; Some See Such Support As Politically Helpful, WASH. POST, Aug. 26, 2002, at A1. 
decided to seek express congressional authorization, its apparent consideration of the 1991 statute as justification highlights an issue that does have enormous bite: How focused must congressional consideration be for it to constitute authorization? Is it necessary that Congress explicitly authorize a particular conflict for it to be constitutional?

I don't mean: Must Congress authorize major conflict by formally declaring war? The issue of whether Congress must formally declare war for large-scale conflict to be constitutional-like the broader issue of whether Congress must authorize sustained conflict - appears to be of great significance for many scholars. I should add that it is hard for me to see that this is actually a difficult issue. Formal declarations of war were increasingly rare at the time of the founding, as Hamilton observed in the Federalist $25,{ }^{5}$ and after 1798 Congress clearly approved the Quasi-War against France without a formal declaration of war. ${ }^{6}$ Background understanding and early practice thus make clear that the framers-in granting Congress the power to "declare war"-were using the term in a non-technical way and did not intend that formal declarations of war were the only mechanism by which Congress could initiate major conflict. Of greater relevance for my point here, the argument that Congress must formally declare war to initiate major conflict is not one that engages with a current controversy. The United States has repeatedly engaged in military conflict since the Second World War without once formally declaring war, and there is no political constituency clamoring for a different practice under which a declaration of war would be necessary.

In contrast, the issue that is of great moment is whether congressional authorization must be explicit and addressed to a particular controversy. As I noted above, my sense is that the current administration considered going to war against Iraq in 2002 on the basis of the 1991 congressional authorization of the Gulf War. During the Clinton administration, the Office of Legal Counsel justified the planned invasion of Haiti in 1994 on the basis of implied authorization found in an appropriations bill, ${ }^{7}$ and in 2000 provided a similar justification for the intervention in Kosovo. ${ }^{8}$ So, the Executive has controversially taken the position that Congress's authorization need not be explicit.

Leading scholars have recognized that there can be disagreement about when Congress has authorized military action in a way that is constitutionally sufficient. There is, for example, an ongoing debate about whether the Tonkin Gulf Resolution was sufficient justification for the War in Vietnam or whether the War Powers Resolution should be understood to authorize sixty days of military action before the Executive needs further approval from Congress. But there has been little thinking about the broader question of how one determines as a matter of law when Congress has signed off on military action and, as the Kosovo and Haiti opinions indicate, this is an opinion of great moment.

A connected issue of similar import is: In what situations is congressional approval unnecessary? Even champions of a pro-Congress understanding of the Constitution,

5. See The Federalist No. 25, at 161 (Alexander Hamilton) (Jacob E. Cooke ed., 1961).

6. See William Michael Treanor, Fame, the Founding, and the Power to Declare War, 82 CORNELL L. REV. 695, 724 (1997).

7. See Deployment of United States Armed Forces into Haiti, 18 Op. Off. Legal Counsel 173 (1994) [hereinafter Haiti].

8. See Authorization for Continuing Hostilities in Kosovo, 2000 OLC LEXIS 16 [hereinafter Kosovo]. 
such as Ely, recognize that there are some situations in which the President can move in advance of congressional authorization-such as when the nation is under attack or to rescue U.S. citizens abroad. ${ }^{9}$ The critical question-and one that has received little attention-is: What are the contours of this category? How do we determine when the Executive can proceed unilaterally? This is, again, a fundamental issue. In the Clinton and first Bush administration, military actions such as Somalia, Haiti, and Bosnia were justified by the Department of Justice on the grounds that the deployment of troops did not amount to "war" in the constitutional sense. ${ }^{10}$ Under the test employed by thenAssistant Attorney General Dellinger, the nature, scope, and duration of the conflict must be assessed. If they do not arise to a certain level, the conflict is not "war," and thus Congress need not approve it." In Somalia, then-Assistant Attorney General Flanigan took the position that the President did not need congressional approval when he deployed troops to protect both U.S. citizens and non-U.S. citizens. ${ }^{12}$ In contrast, the War Powers Resolution suggests the President can act unilaterally only when the United States, its territories, possessions, or troops are under attack. ${ }^{13}$ The gap between the Department of Justice position and the War Powers Resolution is vast. The President's ability to act alone is, under one approach, great; under the other, it is reserved for a particular type of emergency.

Beyond its failure to focus on the issues of primary practical consequence today, a basic failing of most current scholarship on the war powers is that it has not adequately addressed either the question of constitutional role or how political actors should engage in constitutional discourse. Classically, legal scholars have focused either on how courts should interpret the Constitution or on how scholars should interpret it. In recent years, scholars such as Mark Tushnet have pushed to "tak[e] the Constitution away from the courts." I think the case that Tushnet has made is compelling, but we need now to focus more on how political actors should engage in constitutional interpretation. The war powers is an extraordinarily rich area for consideration of this question both because the courts have historically retreated from the area and because there is a significant body of OLC opinions that provides evidence of how one set of political actors has interpreted the Constitution. At the same time, there is a difficult area to think through. How does the presence of a body of executive branch precedent (i.e., the opinions of the Office of Legal Counsel) affect the constitutional interpretations of executive branch actors? Should they interpret the Constitution differently than members of Congress? More broadly, are members of the different branches of government entitled to interpret the Constitution differently precisely because the Constitution in the war powers area contemplates, to use Corwin's phrase, an "invitation to struggle" in which they represent branches of government with different institutional interests. ${ }^{14}$ It is also difficult to work through political actors'

9. See ELY, supra note 1, at 116-18.

10. See Authority to Use United States Military Force in Somalia, 16 Op. Off. Legal Counsel (1992) [hereinafter Somalia]; Haiti, supra note 7; Proposed Deployment of United States Armed Forces into Bosnia, 1995 OLC LEXIS 41 (1995) [hereinafter Bosnia].

11. See Haiti, supra note 7, at 173.

12. See Somalia, supra note 10 , at 11.

13. See War Powers Resolution § 2(c).

14. Edward S. CoRwIN, THE President: OfFICE AND Powers, 1787-1984, at 201 (Randall W. Bland et al. eds., 5th ed. 1984). 
constitutional obligations precisely because the area is so difficult. As the next section will suggest, there are a range of legitimate interpretations to constitutional questions in the war powers area, such as the two I am focusing on here. (What constitutes congressional authorization?; When is congressional authorization unnecessary?) What should a political actor do when there are a range of appropriate interpretations? Should she try to be principled? What does it mean to be principled and what would a principled approach be? Should she, instead, be opportunistic because the constitutional system-like the adversary system-works best when players pursue self-interest, rather than trying to take an Olympian view? These are hard issues that have received relatively little exploration.

Finally, I have found much of the scholarship in this area wanting because it typically treats the question of the proper role of Executive and Congress in the war powers area as an easy one. Scholars disagree about what the proper role is, but, even as they disagree, they treat the position they hold as clearly correct. But, for reasons that will be outlined below, this is not an area that admits of easy answers.

The rest of this paper represents an attempt to start exploring these issues. In the next section, I sketch out why normal methodologies of constitutional interpretation fail to give us concrete answers to my two questions of what constitutes congressional authorization and when authorization is unnecessary. In the final section, I offer an initial foray into why principled decision making is important here and how a political actor might engage in such decision making.

\section{LIMITS OF TRADITIONAL METHODOLOGIES}

When I write a law review article, I typically get a certain number of letters from people who disagree with me. But the only time I have ever gotten truly angry letters was when I wrote about the original understanding of the war powers clause. ${ }^{15}$ What upset people was not my thesis about why the framers gave the power to declare war to Congress, but, rather, the simple fact that, in my view, one could legitimately disagree about what the war clause of the Constitution means. There is a substantial body of scholarly opinion that insists that the constitutional framework is perfectly straightforward, that Congress has to authorize conflicts, and that there is no ground for dispute. As John Hart Ely writes on the first page of his war powers book: "The power to declare war was constitutionally vested in Congress. The debates, and early practice, establish that this meant all wars, big or small, 'declared' in so many words or notmost weren't, even then-had to be legislatively authorized." more ambiguous, and the ambiguity bears on my questions of what constitutes congressional authorization and when it is not necessary.

Start with text. The Constitution vests in Congress the power "To declare War, grant letters of Marque and Reprisal, and make Rules concerning Captures on Land and War." 17 The President is "Commander in Chief of the Army and Navy of the United States"18 and he possesses, as well, whatever power can be derived from the vesting clause of Article II section 1. There are a number of legitimate ways to read

15. See Treanor, supra note 6.

16. ELY, supra note 1 , at 3 .

17. U.S. ConST. art I, $\S 8$, cl. 11.

18. U.S. ConsT. art. II, $\S 2$. 
these texts, and they have different implications for the way my two questions are resolved.

Article I's grant of power to Congress can, as a textual matter, plausibly be read as mandating that Congress must authorize any conflict for it to be constitutional. Under this approach, while Congress is specifically given only the power to start the biggest conflicts (formally declared wars) and the smallest (the limited operations conducted by those operating with letters of marque and reprisal), these grants should be read almost poetically to stand for the proposition that Congress has to approve the biggest conflicts, the smallest conflicts, and everything in-between. Article I, section 8, clause 11 is thus best understood as constitutional synecdoche. (For those with vague memories of the term from long-past high school English classes: The part stands for the whole.) "To declare War [and] grant letters of Marque and Reprisals" is the lawyer's equivalent of "Lend me your ears" and "All hands on deck." Although the synecdoche analogy is original with this essay, the basic point is Ely's. ${ }^{19}$

While the Ely approach to the text would mandate that only congressionally approved conflicts are constitutional, precisely because the text does not speak to the full range of military operation, it does not provide clear guidance as to what form approval must take. In other words, under Ely's reading, Congress can sanction conflict by declaring war, by issuing letters of marque and reprisal, and in other ways that are not spelled out. Thus, this textual approach does not resolve one of my two questions-the question of how one can tell when Congress has authorized conflict. In addition, it does not actually resolve my other question. While this textual approach indicates that the only way the nation can go to war is with congressional authorization, advocates of this view countenance departures from their own textual reading (typically without acknowledging that this is a problem). Thus, as noted, Ely recognizes that there are some emergency situations in which the President can act unilaterally.

Or Article I can be read more literally, in the way that, for example, then-Assistant Attorney General Dellinger did in his OLC opinions. Congress has the power to start war-this is how "declare War" is read, under this approach-and it has the power to issue letters of marque and reprisal. But there are conflicts that fall in betweenconflicts that are not "war"in the constitutional sense because of their limited "nature,

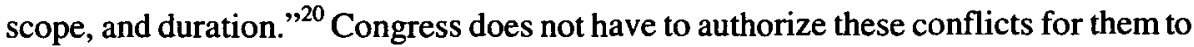
be constitutional. This reading of the text does not resolve how Congress authorizes the conflicts it constitutionally must authorize for them to be legitimate. Under the Dellinger approach, while a formal declaration of war is not the only way for Congress to initiate conflict, the textual reading does not answer the question how, other than through declarations of war and grants of the letter of marque and reprisal, Congress starts war. In practice, the Dellinger approach-with its pro-Executive tilt-led to finding authorization where congressional authorization was not explicit (as in Haiti).

Alternately, Article I can be read very literally, in the way that Eugene Rostow, for example, did. ${ }^{21}$ Congress has the power to declare war. It has the power to issue letters

19. See id. at $66-67$.

20. See Haiti, supra note 7, at 179.

21. See Eugene V. Rostow, Great Cases Make Bad Law: The War Powers Act, 50 TEx. L. REV. 833 (1972); Eugene V. Rostow, "Once More unto the Breach:" The War Powers Resolution Revisited, 21 VAL. U. L. REV. 1 (1986); John Yoo, The Continuation of Politics by 
of marque and reprisal. And that's it. This approach offers a precise answer to my questions. Congress can authorize conflict in precisely two ways-formally declaring war; issuing letters of marque and reprisal. The President cannot do either of these things. Otherwise, he has a free hand.

With respect to the resolution of my two questions, the issue of which of these readings one embraces is critical. But it is far from obvious which of these readings one should embrace. None is baseless, and none is so strong as to command consent.

For a committed textualist, the Rostow reading has a certain power: declare war was a term with significance in international law at the time of the framing, and the founders, he contends, should be understood as intending to incorporate that meaning. Unless one is committed to an acontextual textualism, however, one would find this approach wanting, however, because it is at odds with the originalist evidence. That evidence indicates that the founders intended that the President not be able to lead the nation into war unilaterally. As James Wilson observed, "This system will not hurry us into war; it is calculated to guard against it. It will not be in the power of a single man, or a single body of men, to involve us in such distress; for the important power of declaring war is vested in the legislature at large."22 Although they are legitimately subject to competing interpretations, the records of the Philadelphia convention also support the conclusion that the founders believed that wars should not start without congressional approval. ${ }^{23}$ While the pure textualist might embrace Rostow's reading, then, the reading opens up a door that would allow the Executive to subvert the original understanding fairly completely. ${ }^{24}$

Ely's reading-like Rostow's-has a plausible textual basis: For Ely, the constitutional text means that wars could only be started with congressional authorization. "Declare" meant "start." But like Rostow's reading, Ely's also bumps up against originalist evidence. The debates in Philadelphia indicate that the framers understood the declare war clause to leave to the Executive the power to meet emergencies. When Madison and Gerry proposed that the Committee on Detail's "make war" be changed to "declare," they observed that they would "leav[e] to the Executive the power to repel sudden attacks." ${ }^{, 25}$ Ely's reading of the text does not leave room for military action not authorized by Congress in advance, yet it was clear that the founders intended that - at least "to repel sudden attacks"- unilateral presidential action was permissible. Ely realizes that there were some situations in which the founders countenanced unilateral action, but he does not explain how this can be reconciled with his approach to the text. I should add that Ely's reading is much more satisfactory than Rostow's. Rostow offers a reading of the text that is at odds with the fundamental purpose of the founders, their belief that the President should not have the general power to take the nation into war unilaterally. Ely's reading is much closer to

Other Means, 84 CALIF. L. REV. 167, 244 (1996).

22. 2 DEBAtes on tHE Adoption OF THE FEDERAL Constitution 528 (Jonathan Elliot ed.,1836).

23. See 2 ReCords of the Federal Convention of 1787, 318-19 (Max Farrand ed., 1911).

24. I recognize that my views here are controversial. John Yoo has, for example, argued that a Rostow-type reading is consistent with the original understanding. For reasons outlined in my article, "Fame, the Founding, and the Power to Declare War," I disagree. Proof on the matter is beyond the scope of this essay, and I refer my readers to my earlier work.

25. 2 RECORDS OF THE FEDERAL CONVENTION OF 1787, supra note 23, at 318. 
the founders' vision, but its weakness is that he does not offer a reading of the text that is consistent with his understanding of the Constitution. Moreover, he does not have a compelling explanation of why his vision of the category in which unilateral presidential action is permissible-response to emergencies-is the correct one.

Which leaves us with Dellinger's reading. ${ }^{26}$ Again, it has attractions. Implicitly, he, like Ely, equates "declare" with "start," and that is a textualist reading that squares with originalist evidence. At the same time, by stressing the word "war"-and by interpreting "war" to cover a limited category of conflicts-he avoids the problem that confronts Ely, because Dellinger's textualist reading recognizes, as Ely's does not, that there were some conflicts that did not have to be authorized by Congress in advance. But the problem is that the accent on the word "war" does not capture the types of conflicts that did not have to be authorized. Madison and Gerry were concerned about the need for immediate action, not about exempting limited conflicts. While it may be that the framers would not have understood the word "war" to extend to certain very small scale military conflicts, it is hard to argue that a military action of the scale contemplated in Haiti was not "war," as they understood the term. The strengths and weaknesses of Dellinger's approach mirror the strengths and weaknesses of Ely's approach: Dellinger offers a more capacious view than Ely of the category of situations in which unilateral presidential action is appropriate, but, like Ely, his justification for the contours of that category is not wholly convincing.

Now, afficionados of the textualist turn in modern constitutional jurisprudence may expect me to offer at this point a tour de force textualist reading that is both absolutely novel and that squares perfectly with the originalist understanding. There is, however, no such reading.

This is an admission that highlights the gap between lawyerly practice and historical reality. The lawyer reads constitutional text (or statutory text) in a way that makes sense of it. She does not say, there is a gap between the original understanding and the words the framers chose. Champions of constitutional textualism, such as Akhil Amar, have come to push the approach farther and to ascribe to the founders a sensitivity to words that any poet would envy and an anticipation of future possibility that no seer could even dream of possessing. The framers, however, were not always that careful about what they wrote. Sometimes, of course, they were quite careful. They worried, for example, about representation and spent a great deal of time crafting the result. But other times they weren't so careful. We may, for example, try to reconstruct the original meaning of the contract clause and there is substantial scholarly literature on the topic, but it is hard to figure out what the framers actually intended since the one time they discussed it at the convention they voted it down. Nonetheless, the clause somehow was included in the Committee of Style's draft and nobody seems to have noticed in the hurry to approve the document and adjourn.

If one were to do a chart tracking how closely the framers focused on the various clauses of the Constitution, the declare war clause would appear near the contract clause. As I was drafting this essay, I read Madison's report of the principal debate on the war powers clause aloud. It took me one minute and thirty-five seconds. Moreover,

26. When I refer to Dellinger's view here, I refer to his view as Assistant Attorney General, rather than to the view embodied in his earlier scholarly writings. See Walter Dellinger, War and Responsibility, 50 U. MIAMI L. REV. 107 (1995). 
the people recorded as speaking were by and large not in favor of the clause as adopted - either because they preferred the Committee's proposal of "make" war, or because they thought that the power to declare war should be vested in the President. "Declare" war hardly represents the product of close deliberation that reflects deeply held beliefs. It seems like the formulation was more one adopted because Madison and Gerry were dissatisfied with "make," rather than because they were positively attracted to "declare" and had a clear understanding of what they meant by the term.

This was not a first order issue for them. As a result, they fashioned a text that neither fully captured their intentions nor resolved the types of issues that have become pressing to us. Thus, none of the textual readings is fully satisfactory.

Similarly, the originalist evidence is not dispositive of the two issues that I am highlighting here-the issue of when congressional authorization is necessary and of what constitutes such authorization. As I have noted, with respect to the issue of when authorization is necessary, Madison and Gerry thought the Executive should have the power to repel sudden attacks, and there is no other discussion on point. How do we interpret this brief comment? If Gerry's and Madison's comment reflects the view that the Executive has some power to deal with emergencies while Congress convenes and determines how to act, what are the contours of that power? Is it limited to the specific case mentioned in the debates, of "repel[ling] sudden attacks?" Would it also extend to the protection of U.S. citizens abroad, as in Somalia? Non-U.S. citizens-also in Somalia? How about a pre-emptive strike responding to what the President believes (but Congress does not) is a threat of sudden attack? Does the Executive have other powers beyond the power to address emergencies that allow him to put troops in harm's way? Was it, for example, permissible for President Clinton to deploy troops in Bosnia for peace-keeping purposes, even though there was a risk that they would have to engage in combat? ${ }^{27}$ Could he permissibly send troops into Haiti at the request of the legitimate national government and at a time in which the risk to troops seemed minimal $?^{28}$ The historical record is far too thin to permit us to answer these questions. While the originalist evidence does not support the Rostow view that there was a general executive power to initiate conflict without congressional approval, the contours of the exception suggested by Madison and Gerry are highly debatable, and both the Ely and Dellinger views have a plausible originalist basis.

A similar point can be made about the originalist view on what the appropriate forms for Congress to authorize conflict were. If one rejects Rostow's reading of the text on the grounds that it is at odds with the generally expressed view that wars should not start without congressional sanction, then one can conclude that the founders anticipated that there were mechanisms other than declarations of war and grants of letters of marque and reprisal for commencing hostilities. But there is no clear understanding of what those alternate mechanisms would be. Again, this open issue is critical in terms of current practice. For example, in 2000, Congress both rejected a concurrent resolution authorizing military operations in Kosovo and, at a time in which the War Powers Resolution provided that an appropriations statute did not constitute authorization for military action, nonetheless enacted a statute specifically funding military operations in Kosovo. Did the Executive, operating against this backdrop,

27. See Bosnia, supra note 10.

28. See Haiti, supra note 7, at 189. 
have congressional authorization for its operations in Kosovo, as it concluded it did because of the appropriations statute? ${ }^{29}$ Given the founders' limited focus on the question of congressional authorization, these are not the type of issues on which the original understanding is clear.

Other interpretive guides are similarly unsatisfactory. English precedent is unhelpful. The founders were rejecting the English model, under which the Executive was charged with deciding when to start conflict (although one can debate how completely they were rejecting that model). One therefore cannot map previous practice onto the original understanding.

Separation of powers principles are also unhelpful to working out the types of issues that are the subject of current controversy. The founders vested different powers in the different branches, as noted above, but it is precisely the contours of these powers or the trumps when the powers conflict that are unclear. Judicial precedent is also particularly unhelpful because the courts have largely avoided the area.

Nor does evolving tradition yield answers. While one can trace a general expansion of executive power in the war powers area-and this is certainly the case in the years since the Second World War-that expansion has been highly (if episodically) contested by Congress. Thus, this is not the type of situation in which one can say that we the people have evolved to a new consensus that alters the constitutional framework.

In sum, the methodologies which one normally relies on do not yield clear answers to the questions of what constitutes congressional authorization and when it is not necessary. In the next section, I discuss how political actors should respond to this uncertainty.

\section{PRINCIPLED DECISION MAKING}

Evaluation of the constitutional jurisprudence of a judge properly proceeds along two tracks. First, we should look at what her fundamental constitutional commitments are and how they are linked to her constitutional jurisprudence. For example, she may be committed to majoritarian rule and embrace originalism (or a textualism that tracks original usage) as a result. Or she may be fundamentally committed to liberty or equality, and she may construe the Constitution as embodying that commitment. Analyzing a judge's work in this way, we can assess whether her commitments are normatively appealing to us, whether they are our commitments. Second, we should look at whether particular stances she takes in specific cases or when she addresses particular constitutional questions are consistent with her overall constitutional jurisprudence. Here, we are assessing whether her decisions reflect adherence to the rule of law or whether they are driven, instead, by a desire for a particular outcome. When we find that a judge resolves a particular controversy in a way that is inconsistent with her overall jurisprudence, that is a telling criticism. And so, for example, when scholars contend that Justice Scalia's decisions in Printz and Lucas fail to accord with his textualist methodology, that is offered as a sharp critique.

We do not apply the same standards when we review the constitutional jurisprudence of political actors. We don't expect the same consistency. Scholars will

29. See Kosovo, supra note 8 . 
still occasionally point out divergences-I recently read, for example, a work that criticized Senator Biden for having made inconsistent statements about evolving constitutional meaning during the Bork and Thomas confirmation hearings-but we rarely try to make sense of political actors' views in the same way that we try to make sense of judges' views, and, when inconsistencies are found, the point generally made is that the politician is a politician and that this is what politicians do.

If we are to take the Constitution outside of courts seriously, however, this dual standard is inappropriate. If political actors are to be treated, as they should be, as constitutional actors whose interpretive role is as significant as the interpretive role of courts, their constitutional acts should be measured against precisely the same standards we use when assessing judicial acts. We should ask: What normative vision does the constitutional actor adopt? Is a particular action consistent with that vision or is she disregarding her overall vision to achieve a particular outcome? If political actors cannot satisfy the same standards of consistency that we apply to judges, then their constitutional commitments are not truly their constitutional commitments. They are policy views dressed as constitutional commitments.

What does this mean to the political actor confronting a war powers question, such as when congressional authorization is not necessary or what constitutes congressional authorization? As I have previously suggested, there are a range of principled stances that one could take in resolving these problems. In deciding which to follow, the political actor should seek to adopt one of these stances on the basis of principle, rather than out of a desire to further a particular policy outcome in a particular case.

Principle in part means that the individual should take a consistent approach to constitutional interpretation. The war powers area is one in which, famously, right and left are attacked for abandoning their normal methodologies. People on the left, like Ely, are criticized for embracing originalism here; people on the right, such as Meese, are criticized for rejecting it in this context. This criticism is significantly overstated. I believe that Ely's writing here can be squared with his writings in other contexts. Similarly, as I suggest in the last section, the questions of what the original understanding was and how the text should be read are more complicated than generally thought, particularly as they apply to the questions of congressional authorization on which I am focusing here. Nonetheless, principled decision making means that one should not embrace an approach in the war powers context that is at odds with the approach to constitutional interpretation one takes elsewhere. For example, one should not embrace the strict textualism that Rostow favored with respect to the war powers without being willing to apply it consistently to other questions of constitutional meaning. Consistent embrace of an overall methodology means that the reading of the particular constitutional clause — such as the declare war clause - reflects rule of law concerns, rather than a particular policy vision. It also allows the citizen to decide if she finds that methodology normatively attractive. For me, for example, the Rostow approach is flawed, not because it is internally inconsistent, but because I see no good reason to privilege a strict reading of text when that reading leads to a result inconsistent with original purpose.

The Ely and Dellinger views, in contrast, do not suffer from this weakness. Whereas Rostow privileges text over original understanding, Ely's and Dellinger's views reflect what I find to be a more appealing attempt to make sense of both original meaning and text in a situation in which these two determinants of constitutional interpretation do not perfectly align, in which the contours of original meaning are very unclear, and in which the other determinants of constitutional meaning (such as tradition and judicial 
precedent) shed little light. Because they are sensitive to the full range of constitutional determinants in a way that I find appropriate, both the Ely and Dellinger views are attractive to me as a way to think about constitutional commitments in the war powers area. They are satisfactory in the way that a judge's interpretive methodology is satisfactory. Neither is clearly right, but it is because this is not a reason that admits of clearly right answers.

So, how would one choose between them in trying to decide when congressional authorization is necessary and what constitutes congressional authorization? I should say at the outset that policy views about a particular controversy are not an appropriate basis for choosing between the two views. This is not simply because I believe that commitment to the rule of law dictates that principled decision making should govern constitutional interpretation outside of courts; it is also because an outcome-driven approach to constitutional interpretation can also quickly backfire. There is a tendency to assume that the right is more war-like than the left, but history teaches that neither the right nor the left is consistently more activist or more opposed to military action than those on the other end of the political spectrum. If one were to list the major military conflicts and potential conflicts of the past century or so-starting with the Spanish American War and running through the First World War, the Second World War, Korea, Vietnam, Grenada, Panama, Iraq, Somalia, Haiti, Bosnia, Rwanda, Kosovo, Afghanistan, and Iraq-there is no clear right/left split on the appropriateness of military action by the United States. Sometimes the left is more aggressive; sometimes, the right is more strongly in favor of military action. Any attempt of a party or faction to adopt a constitutional vision of the proper role of the President and Congress in order to advance a particular policy end in a particular controversy is thus short-sided.

If, however, history shows that right and left do not take consistent views on the question of how aggressive the nation's military policy should be, it also shows that the Executive and Congress do take fairly consistent views. With the exception of the Spanish American War-where Grover Cleveland and, less clearly, William McKinley were more reluctant to intervene than Congress - the Executive has been consistently more war-like than Congress over the past hundred years. In my article, I suggested that this reflects the different reputational consequences of war for members of Congress and for the President. The founders were aware of this. As Madison wrote in his Helvidius letter:

In no part of the constitution is more wisdom to be found than in the clause which confides the question of war or peace to the legislature, and not to the executive department. Beside the objection to such a mixture of heterogeneous powers: the trust and the temptation would be too great for any one man; not such as nature may offer as the prodigy of many centuries, but such as may be expected in the ordinary successions of magistracy. . . . It is in war, finally, that laurels are to be gathered, and it is the executive brow they are to encircle. The strongest passions, and most dangerous weaknesses of the human breast; ambition, avarice, vanity, the honorable or venial love of fame, are all in conspiracy against the desire and duty of peace. ${ }^{30}$

30. James MAdison, Hel vidius No. 4, in 15 THE PAPERS OF JAMES MADISON 106 (William T. Hutchinson \& Jean Schneider eds., University of Chicago Press 1962-1985) (1793). 
Presidents will get the lion's share of the credit for a successful war and the lion's share of the blame for tragic consequences of inaction. After length of tenure in office and whether they were assassinated, the number of years in which the nation was at war during a Presidency is the variable weighing most heavily in favor of a President's historical reputation. While they will also get most of the blame for losing a war, the nation's overall record in war-the fact that, with the exception of Vietnam, we have either prevailed or, in the case of the War of 1812, more or less tied-means that Presidents have an incentive to lead the nation into war. Members of Congress do not have a similar reputational reason to favor conflict.

When we are filling in gaps in the constitutional structure-and, when we determine what constitutes congressional authorization or when authorization is not necessary, that is what we are doing-this is precisely the type of large structural concern that should weigh heavily. In choosing between the Ely and Dellinger models, we should think about whether it makes most sense to interpret the Constitution in a way that accords the President greater freedom of action or one that restrains him by interpreting the Constitution in a way that gives Congress a greater role. Looking at the past, I don't think there is an easy answer to this question.

In this area of indeterminacy, a dialogic model of constitutional interpretation has particular force. Partisans of a strong presidency-a la Dellinger-have a solidly grounded position, and it affords an appropriate basis for executive action. But critics of that view-a la Ely_also have a soundly grounded position, and it, too, affords an appropriate basis for governmental action; it is the language by which champions of Congress can challenge executive action and seek to rein in the Executive.

Ultimately, the discourse may lead to an evolution of our constitutional traditions. One view or the other may so consistently prevail so that an answer is provided in an area in which the original understanding and text (and separation of powers doctrine and judicial precedent) do not lead to a clear answer.

Or, as is more likely the case, the dispute will continue. And this is a significant difference between constitutional making inside the courts and outside the courts. Within the courts, it is more likely that one view will prevail. There is a clear arbitrator. Constitution making outside the courts is more free-form, more unsettled, since it does not have one decision maker at the apex in the way that the Supreme Court is a decision maker.

At the same time, there can be a real thickness to the constitutional discourse among political actors, in the same way that judicial decision making is the product of a thick discourse. Political actors can and should look at precisely the same types of concerns that motivate courts: the text, founders' vision, history, institutional concerns. The war powers area offers a model for thinking about constitution making outside the courts, and it suggests that constitution making outside the courts is properly not that different from constitution making inside the courts. 